$\frac{\text { DE }}{G}{ }^{\text {DE GRUYter }}$ THEN

EJAE 2017, 14(2): 43-57

ISSN 2406-2588

UDK: 339.13:621.311(4-12)

$338.5: 621.31$

005.334:621.31

DOI: 10.5937/ejae14-14849

Original paper/Originalni naučni rad

\section{THE OPTION ON ELECTRIC ENERGY FOR THE DECREASE OF RISK ON THE EXAMPLE OF EEX (EUROPEAN ENERGY EXCHANGE)}

\author{
Tatjana Latas ${ }^{1 *}$, Zoran Jeremić ${ }^{2}$ \\ ${ }^{1}$ Somborelektro, \\ Sombor, Serbia \\ ${ }^{2}$ Singidunum University, \\ Belgrade, Serbia
}

\begin{abstract}
:
Electricity market deregulation and liberalization have led to high volatility on power exchanges, which require the use of derivatives in energy markets for more efficient risk management which the participants at the market are exposed to. The available options are one of the derivatives that have entered liquid markets. Therefore, this paper presents an example from the most developed energy exchange EEX (European Energy Exchange), with the aim of applying verified scientific methods to check the practice of functioning of liquid energy market, by using options to reduce the risk. The most frequently used models for hedging future open positions and evaluation of premium on options in practice are the Black - Scholes and Black 76 model, which are therefore presented in the text. South East European Power Exchange (SEEPEX) has started operating in Serbia. Its development is going to be via integration with regional markets in the direction of integration of the total electric energy market in Europe. That path will be long, but it has already required the knowledge of market instruments used in trading and risk management at the power exchanges. Presented results refer to the essential knowledge of dynamic variables that options bring into the energy market in order to reduce the risk.
\end{abstract}

\section{Keywords:}

electric energy exchange, derivatives, options.

\title{
INTRODUCTION
}

By passing the Law and Bylaws on Energetics in 2015 and 2016, the legal and regulatory frame for the development of the electric energy market in Serbia was designed. In February 2016 the electric energy exchange SEEPEX was put in operation and it was formed on the basis of the partnership between Elektromreze Srbije (EMS a.d.) and EPEX SPOT (European Power Exchange) as a shareholder company (EMS, 2016). SEEPEX manages organized market with standardized products and delivery within a-day-in-advance time frame. Trading at this exchange is in the initial stage and for now, it has operated on the spot market only. Further development of the exchange may lead to the connections 
of regional exchanges and their integration into European exchanges where the trading with derivatives is conducted: futures, forwards, and options. Due to that fact, it is useful to expand the knowledge and research related to trading with derivatives on electric energy in Serbia. In this paper, the subject of study will be trading with options on electric energy. It will conclude with an example of options trading at the European Energy Exchange - EEX as one of the most developed and liquid power exchanges.

In this paper, we would like to present the alternative to the scientific truth, by analyzing options trade on EEX in order to find out complex responses (social, economic, financial, and legal) to the question of how they do it successfully in relation to us. The main objective is to present the best practice in trading options, having in mind that SEEPEX is at an early stage of development and that derivatives market still does not exist.

Electric energy is goods impossible to store and it is consumed in continuity from second to second. The demand for electric energy in a short period is inelastic in terms of price. Empirical research studies indicate that the demand declines when the price within a short period increases, but the effects of price increase are minimal. If the costs of electric energy have no significant influence on the total costs of a consumer (whether households or industrial consumers), they will not reduce the consumption owing to sudden price changes but will accommodate the demand in the long term. Due to the lack of economically sensible storage possibilities, supply and demand need to be in balance at any moment in time. Futures markets behave according to the expectation theory since they have to anticipate supply and demand during the period of delivery of future contract (Fritz, 2012).

The participants of the electric energy market such as producers, suppliers, deliverers, and other participants capable of managing risks use different financial tools. Among others, there are future and forward contracts, swaps, and options. The stated contracts are different with respect to obligations which are imposed on the participants of the market and the manner of offset of receivables and payables. While the contract on futures and forwards obliges the buyer and seller to execute it, the option is in this respect obligatory only for its holder (seller).

The most important goal of the spot market at each exchange is to enable trading of standardized product and provision of market information, competition, and liquidity. Power exchanges (in an ideal case) also provide other benefits, such as neutral trading place, referential prices, easy access to trading, low transaction costs, safe balancing (Madlener \& Kaufmann, 2002). Apart from that, spot markets are an important reference for bilateral trading and "over the counter" market but also the basis for the establishment of the derivative market. In order to establish the trading with futures, forwards and options, a liquid market of satisfactory performances must be established.

It is very difficult for the power exchanges to reach these ideal performances of spot markets, primarily due to the nature of electric energy as a very specific trading object (storage impossibility, transmission problem, network congestion, season character, peak load...). These characteristics, especially storage impossibility, create a volatile day to day behavior of varying degrees (Pilipovic, 2007). The use of options at the electric energy market as a type of derivative is not as widespread as it is the case with options on other goods markets. One of the power exchanges where the options market is present is EEX Leipzig. This exchange is highly liquid, which is one of the most important conditions for the establishment of the options market. The paper analyzes the use of options on electric energy and provides an example of how they are exercised at the biggest mid-European exchange of electric energy EEX. 


\section{OPTIONS TYPES AND WAYS OF THEIR EXERCISE}

The option, as a financial tool, gives its holder a right to buy or sell a certain amount of underlying assets until the exercise day or on the exercise day per fixed, in advance determined price (strike price). The strike price is the price fixed in the option according to which its owner may purchase or sell securities or other related assets which is the subject of the option. This is the price that the holder of the option uses to speculate about the increase or decrease of the securities prices (Orsag, 2006).

The basic characteristic of options is that the option buyer (option holder) is not obliged to complete the transaction unlike the option seller (option writer) who is obliged to respond to the request of the option seller. Therefore, the option buyer pays the price of the option which is called premium. The value of the right of the options holder stems from the value of the underlying assets (shares, exchange index, foreign currencies, debt tools, goods and future contracts), while on the electric energy market they are exercised based on the future price which is designated based on the concluded future contract. The buyer of the option, i.e. option holder may exercise the stated option until its exercise day. The seller of the option, i.e. option writer is obliged to take into consideration all the items from the contract on the stated option (Tešnjak et al., 2009).

There are two basic types of options on the derivatives market (Eydeland \& Wolyniec, 2003) namely (Hull, 2005): call and put. A call option gives its holder the right to buy underlying assets based on the price determined in advance (fixed price) until the exercise day or on the exercise day. A put option gives its holder the right to sell underlying assets at the price determined in advance (fixed price) until the exercise day or on the exercise day.

The option holder, for the acquisition of the right to buy or sell certain assets, pays the premium to the option writer. During the trade with options, the option holder always takes a long position and the option writer takes a short position. Continuing from the long and short position, different relations between the option writer and holder are possible.

\begin{tabular}{cccc}
\hline \multicolumn{4}{c}{ Option } \\
\hline Call (Buy option) & Put (Sell Option) \\
\hline $\begin{array}{c}\text { Long position - to buy } \\
\text { call option }\end{array}$ & $\begin{array}{c}\text { Short position - to sell } \\
\text { call option }\end{array}$ & $\begin{array}{c}\text { Long position - to buy } \\
\text { put option }\end{array}$ & $\begin{array}{c}\text { Short position - to sell } \\
\text { put option }\end{array}$ \\
\hline $\begin{array}{c}\text { The right to buy per } \\
\text { strike price }\end{array}$ & $\begin{array}{c}\text { Must be delivered per } \\
\text { strike price in case of } \\
\text { option exercise }\end{array}$ & $\begin{array}{c}\text { The right to sell per } \\
\text { strike price }\end{array}$ & $\begin{array}{c}\text { Must accept the delivery } \\
\text { per strike price in case of } \\
\text { option exercise }\end{array}$ \\
\hline
\end{tabular}

Table 1. Review of positions of option holders

The option holder takes the long call or long put position. Purchasing protects the holder from an increase, i.e. long call and decrease, i.e. long put of the prices of the subject asset with keeping the possibility of purchase per lower price, i.e. long call and selling per higher price i.e. long put in case of the change of the price of the subject asset. In case of buying of the option, the loss is limited to the price of the option and the amount of the premium.

The option writer assumes short call or short put position. The writer writes the call option when it is expected that the prices of the subject asset will remain at the same level or decrease (short call) or 
grow (short put). In case of the price change to higher (in case of call option) or lower (in case of the put option), their loss is potentially limitless. The profit of the option writer equals to the loss of the option holder and vice versa - zero sum game (Jeremić, 2012).

There is a standard set of assumptions which determine the most frequently traded plain vanilla options. Plain vanilla is a colloquial expression of the derivative market for labelling typical options from the standpoint of their basic investment features. Thus, plain vanilla is comprised according to related assets, the standard manner of determination of the strike price and the manner of exercise as well as the standard time until the validity expiration (Orsag, 2006). The options which use non-standard assumptions are usually called exotic options. In order to use an exotic option, it is necessary to know what is going on in real life. The basic formula of these options is: "I can be used if $\mathrm{x}, \mathrm{y}$, and $\mathrm{z}$ are true". It is up to the user to evaluate whether $\mathrm{x}, \mathrm{y}$, and $\mathrm{z}$ are true in their case (Edwards, 2010). Exotic options, actually, represent non-standard American and European options. Exotic options comprise LEAPS as long-term options, Bermuda options because of the modification of the exercise possibility, border and binary options as well as many other modifications of basic features of options (Orsag, 2006). Usually, standard and plain vanilla options are included in the options exchanges and have developed a secondary market. Exotic options are most frequently trade subjects at agreed markets and they represent certain financial innovations which are produced by different financial institutions in order to satisfy the requests of their customers for specific financial services (Orsag, 2006). Apart from the plain vanilla option at EEX exchange, the spread options are also traded with. EEX offers locations spread products for selected financially established futures for electric energy. Spread options enable participants to efficiently trade with the differences in price between different areas of delivery.

In order to determine the value of options primarily, it is necessary to determine the following parameters:

1. Underlying assets (assets traded on spot markets (securities, goods, currencies), futures contracts, indexes)

2. Option type according to the right it offers (call or put)

3. Taken position (long or short)

4. Manner of option exercise (American, European, Asian)

5. Option class - according to calendar (annual, trimester, monthly), payoffs manner (financial or physical), spot goods (option with fixed price of underlying assets, daily option, and option with floating price of the underlying assets that is index and monetary option)

6. Execution price (different from the price on the spot or futures market)

7. Quantity of the related assets (quantity used for trading within one contract).

Mathematical models for determining the option value have been developed for more than a hundred years, but they experienced the boom in 1970s due to the Black-Scholes formula which designates the theoretical value of options. After that, other mathematical models such as the bionomic tree model and later the Monte Carlo model were developed. The aim is to determine values of the options at the level that is as realistic as possible (Hull, 2005). 


\section{DEVELOPMENT OF OPTION PRICING MODELS}

According to Salvatore (1994), the risk refers to the situation where the decision has more than one possible outcome and where the probability of each specific risk is known or can be estimated. Therefore, the risk requires that the decision maker knows all possible outcomes and has some idea of the likelihood of each of them, as the greater the number and range of possible outcomes, the greater is the risk of making a decision. Trading with options involves high risks, both for the option writer and option holder and they are specific compared to risks of options whose basis is in other trading objects, such as shares or exchange goods. If the option is not realized on time, its value may decrease immediately, which means that loss has been incurred. Depending on the increasing or decreasing value of the option, options can be in-the-money, at-the-money or out-of-the-money. In-the-money call option is the option whose exercise leads to profit, which means that the value in the case of the call option is lower and in the case of put option higher than the price of current assets. This type of option should be exercised. Value of at-the-money option is equal to the current value of underlying assets. Opposite to in-the-money option is the out-of-the-money option, where the option has higher value in case of call option and lower value in case of put option than the current price of underlying asset. The risk impact is therefore very prominent in the determination of option value.

Modern techniques for evaluation of options based on stochastic calculation are frequently considered one of the most complex mathematical forms applied in finances. The stochastic process used to model a commodity price, should capture all specific characteristics of the commodity (seasonal variation in volatility, occasional price spikes, and tendency to quickly revert to the average cost of production) (Blanco et al., 2001).

Contemporary mathematical models stem from the 19th century when Charles Castelli published the book "The Theory of Options in Stocks and Shares" in 1877, in which he presented concepts of hedging and speculating with options. Twenty-three years later Louis Bachelier in his dissertation from 1900 entitled "Theorie de la Speculation" presented first mathematical solutions for analytic evaluation of options (Mishra \& Debasish, 2007). Bachelier's paper was ahead of its time for years and in some aspects even for decades. He was the first one to apply Brownian motion as the model for calculation of share price (Davis, 2001), even 5 years prior to Einstein's application of Brownian motion in physics. Intrigued by Bachelier's work, Paul A. Samuelson wrote an unpublished paper entitled "Brownian Motion in the Stock Market” in 1955. Also, in the same year, Samuelson's student Richard Kruizenga quoted Bachelier's work in his dissertation entitled "Put and Call Options - A Theoretical and Market Analysis". In 1962 A. James Boness in his dissertation, "A Theory and Measurement of Stock Option Value" presented the model for option evaluation, which represents an important theoretical contribution to the determination of theoretical option values (Mishra \& Debasish, 2007). Fischer Black and Myron Scholes presented their mathematical model for designation of option values in 1973. Their model is based on certain assumptions among which the most important is the one that the price of the basic assets follows geometric Brownian motion. This model is applicable only to the spot price of basic assets. Only a few years later, in 1976 Fischer Black developed the modified version of the BlackScholes formula and produced the formula known as Black 76 which is used to calculate the option value on the basis of forwarding price of the subject assets.

The Black-Scholes and Black 76 formulae are suitable for those options which can be exercised only on their exercise day (such as the European type of options). However, when options are exercised on some other day before their exercise day (American type of options), another model for determination 
of option value has to be applied. One of these models is the model of binomial tree which was presented for the first time in 1979 by Cox, Ross \& Rubinstein in the paper entitled "Option Pricing - A Simplified Approach" (Mishra \& Debasish, 2007). The values of an option which consists of more complex elements are calculated using the Monte Carlo method which includes the simulation of accidental variables. Today this method is frequently used and popular among mathematicians.

\section{THE BLACK-SCHOLES AND BLACK 76 MODELS}

The Black-Scholes model is a theoretical base for European put and call option on non-dividend paying stocks. The major argument is that long position could be riskless hedged with the short position in the stock and that hedged ratio could be adjusted continuously (Mishra \& Debasish, 2007). The Black-Scholes model provides non-risky interest in the form of discount factor. The Black-Scholes model is based on the following assumptions (Black \& Sholes, 1973):

- The price of the subject asset follows geometric Brownian motion,

- There is a possibility of sale of the subject asset,

- There is no possibility for arbitrage,

- Exchange trading is continuous,

- There are no transaction costs or taxes,

- There is non-risky interest rate and it is constant during the period of trading with options.

The Black-Scholes formula based on presented assumptions provides the value of call option for the subject asset per spot price $\mathrm{S}$, and agreed price for the specified option $\mathrm{K}$, i.e. the price per which the subject asset will be bought in future time period T. The non-risky interest rate $\mathrm{r}$ and volatility which is the reflection of spot price of the subject asset are constant. The Black-Scholes formula for the call option is (Black \& Scholes, 1973):

$$
\mathrm{C}(\mathrm{S}, \mathrm{T})=\mathrm{S} \cdot \mathrm{N}(\mathrm{d} 1)-\mathrm{K} \cdot \mathrm{e}-\mathrm{rT} \cdot \mathrm{N}(\mathrm{d} 2)
$$

And for put option:

$$
P(S, T)=K \cdot e-r T \cdot N(-d 2)-S \cdot N(-d 1)
$$

where:

$$
\begin{aligned}
& \mathrm{d} 1=\ln (\mathrm{S} / \mathrm{K})+(\mathrm{r}+\sigma 2 / 2) \times \mathrm{T} / \sigma \sqrt{\mathrm{T}} \\
& \mathrm{d} 2=\mathrm{d} 1-\sigma \sqrt{\mathrm{T}}
\end{aligned}
$$

$\mathrm{N}$ stands for the cumulative function of probability for standard normal distribution.

According to the Black-Scholes formula, the realistic market value of the call option is the difference between an expected value obtained from the direct purchase $(\mathrm{SxN}(\mathrm{d} 1)$ and a present value of the option price at the moment of its exercise $(\mathrm{K} \cdot \mathrm{e}-\mathrm{r} \cdot \mathrm{T} \cdot \mathrm{N}(\mathrm{d} 2))$. The same analogy is to be applied to the put option.

In 1976 Fischer Black created his own model for evaluating options which instead of spot price uses the forward price of the subject asset for calculating the option value. The following formulas for determining the value of call emerge from that (Black, 1976): 


$$
C(F, T)=e-r T \cdot(F \cdot N(d 1)-K \cdot N(d 2))
$$

And put option (Black, 1976):

$$
P(F, T)=e-r T \cdot(K \cdot N(-d 2)-F \cdot N(-d 1))
$$

where: $\mathrm{r}$ - stands for non-risky interest rate, $\mathrm{F}$ - stands for the forward price of the subject asset on the exercise day of the option, $\sigma$ - stands for the volatility of the forward price and $\mathrm{N}(\ldots)$ - stands for the function of the normal cumulative distribution. The assumptions and manners of application of the Black 76 formula are the same as those of the use of the Black-Scholes formula, except for the replacement of the spot price of the subject asset with the forward price which represents the expected future value discounted for a non-risky rate.

\section{REALIZATION OF OPTION AT EEX}

The options were introduced to the electric energy trading for the first time at NYMEX (New York Mercantile Exchange) in 1996 (Pavlatka, 2010). In Europe, however, they are mostly traded within EEX. EEX is the exchange situated in Leipzig, which is one of the rare markets of electric energy on which the trading with options may be done, primarily because the precondition for trading with options is the high liquidity of the market. Also, high volatility at futures market and expanded offer of options lead to the $180 \%$ growth in comparison to 2015 in trading with options (EEX, 2017a). EEX exchange offers trading with European type options, exercise in monthly, quarterly and annual futures contracts for the delivery of base electric energy. The options at this exchange may be exercised in a way that participants of the market assume a certain future position, which means that the basis of the option is the forward price of electric energy and joined futures contract. The advantage in comparison with the futures contract is that the holder of call or put futures option keeps the possibility of unlimited profit with the restriction of potential losses due to unfavorable movement of base assets, in this case, electric energy.

Options on futures contracts for electric energy will be delivered are traded with at EEX exchange. The options that are traded with are of the European type (may be exercised only on the last day of trading). The premium must be fully paid one day after trading. The options are exercised on the basis of monthly, quarterly and annual futures contracts for electric energy. The options that are traded with are options on Phelix Base Futures (Phelix - index of prices at hourly auction for German/Austrian delivery zone), Options on French Base Futures, Options on Italian Base Futures and Options on Spanish Base Futures. Options on Phelix Base Futures are available for different delivery periods as follows: 5 monthly (Phelix Base Month type), 6 quarterly (Phelix Base Quarter type) and 3 annual (Phelix Base Year type) delivery periods (EEX, 2017b).

For Phelix Base Year Options EEX also established the options with short-dated options with quarterly expires (Phelix Base Year Future Short Dated type). The rules of EEX exchange stipulate that options are due the moment when trading with them is conducted for the last time. Therefore, the last day of trading for the option of the Phelix Base Year Option type is on the second Thursday in December. For the options of Phelix Base Month Future for January type according to which the delivery of electric energy is in January and Phelix Base Quarter Future for the delivery in the first quarter of the year the last day of trading is on the third Thursday in December. The last day of trading for all other 
options of the Phelix Base Quarter Future, Phelix Base Month Future and Phelix Base Year Future Short Dated types is four days before the beginning of delivery of electric energy.

The options established for the new markets, Options on French Base Futures, Options on Italian Base Futures and Options on Spanish Base Futures are available for 2 monthly, 2 quarterly and 2 annual delivery periods. Their exercise is the same as with the Option to Phelix Base Futures contracts. For new markets, there are still no available options with short-dated options with quarterly expires.

The minimum unit for trading is one contract. The contract may be monthly, quarterly and annual. The monthly contract is calculated by multiplying the number of days in the month with 24 hours and adjusted to daylight saving time. The quarterly contract is calculated by multiplying the number of days in the quarter with 24 hours and adjusted to daylight saving time. The annual contract is obtained by multiplying 365 days with 24 hours. The prices are expressed in EUR/kWh, calculated to no more than three decimals, with the least possible change of $0.001 \mathrm{EUR} / \mathrm{kWh}$. The value of the contract is the product of the contracted volume of trading and option price. For instance: if the premium for annual option is $1,000 \mathrm{EUR} / \mathrm{MWh}$, the contracted value amount is $8,760\left(24^{\star} 365\right) \mathrm{MWh} \times 1,000 \mathrm{EUR} / \mathrm{MWh}$ $=$ EUR 8,760.00. The value of the position is obtained by multiplying the value of the contract with the number of contracts. In this case, if there are, for example, 10 contracts, the value of the position would be $10 \mathrm{x}$ EUR 8.7600,00 = EUR 87,600.00 (EEX, 2016).

For the evaluation of options at EEX exchange, the Black model (Black 76) is used. The main influencing parameters are underlying future price, exercise price, the residual term, the short-term risk-free interest rate and the implied volatility of the underlying security. The implied volatility is established by EEX and is based on other price sources, historical data or is specified by the chief trader procedure (EEX, 2017c). The table presents the parameters used for the evaluation of options and their influence on the option price (EEX, 2016).

\begin{tabular}{lccc}
\hline Parameters & Variables & Call & Put \\
\hline Underlying price & $\mathrm{F}(\mathrm{t}) \uparrow$ & $\uparrow$ & $\downarrow$ \\
\hline Strike price & $\mathrm{K} \uparrow$ & $\downarrow$ & $\uparrow$ \\
\hline Interest rate & $\mathrm{r} \uparrow$ & $\downarrow$ & $\downarrow$ \\
\hline Expected volatility & $\sigma \uparrow$ & $\uparrow$ & $\uparrow$ \\
\hline Time until expiration & $\mathrm{t} \downarrow$ & $\downarrow$ & $\downarrow$ \\
\hline
\end{tabular}

Table 2. Parameters for options evaluations and their influence of the option price (EEX, 2016)

The intrinsic value of the call option represents the difference between the forward price $(\mathrm{F}(\mathrm{t}))$ and strike price $(\mathrm{K})$. If the difference between the term and strike price is less than zero, the option value is zero. The intrinsic value of the option represents the difference between the strike price $(\mathrm{K})$ and forward price $\mathrm{F}(\mathrm{t})$. Also, if this difference is less than zero, the value of the option is zero. The intrinsic value of the option cannot be less than zero. The time value of the option is equal to the difference between valid premium and valid actual value. It is determined by time, interest rate and volatility (EEX, 2016)

The increase in price of the base futures contract leads to increase of the price of call option and decrease of the price of put option. The situation with the increase of strike price is opposite, higher strike price results in the lower price of call option and higher price of put option. The increase of interest rate 
influences the decrease of the option price, while the higher volatility of the price of underlying assets influences the increase of the option price. The shorter the exercise day, the lower is the option price.

The rules of trading oblige the option holder to pay the premium in order to gain the right to exercise the option. The option holder protects himself from the market risk. The option writer is obliged to cover the margins, while in the case of futures contracts buyer and seller are obliged to cover the margins to ensure the exchange liquidity. In options trading, only the option writer is obliged to cover some margins, while the option holder pays the premium to the option writer. Upon the request of the clearing company which represents an individual member of the exchange in charge of the collection of assets for covering margins, the option writer is obliged to cover the premium margin and additional margin. The premium margin covers for the losses which are the result of insufficiently paid premium and the additional margin losses which are the result of the changeable value of that premium. The volume of these margins depends on the current position of the option holder. If the option writer is forced to step away from the position, on that occasion during the sale of the option they must cover the premium margin which is then adjusted to the new price of the option on the daily basis. These margins are calculated based on the mark-to-market method, i.e. the method of adjustment of premium values to the market value of the option. This means that daily reevaluation and settlement of profits and losses (settlement price yesterday $v s$ settlement price today) is made (Eurexchange, 2017). Due to this method, the exchange secures its further liquidity. Premium margin corresponds to the premium for buying the option so it is calculated in the following manner (EEX, 2016):

$$
\text { Premium margin }=\text { Position } \mathrm{x} \text { contracted quantity }(\mathrm{MWh}) \times \text { Calculated price }(\text { EUR/MWh })
$$

The premium margin is used in the final calculation of the position which refers to the current market price of electric energy.

The additional margin is the reflection of the most unfavorable price movement so in accordance with that, it is calculated in the following manner (EEX, 2016):

$$
\begin{aligned}
\text { Additional margin }= & \text { Position } x \text { contracted quantity }(\mathrm{MWh}) \mathrm{x} \\
& \text { the most unfavorable option price movement }(\mathrm{EUR} / \mathrm{MWh})
\end{aligned}
$$

With this margin, it is possible to establish the upper and lower limit of the expected future price of electric energy. The designed value of the option is designated using the Black 76 formula. An example of the calculation of the premium and the additional margin is presented in Table 3 . The model of calculation of margins from Table 3 cannot be adopted if the option value is significantly lower than its realistic value, i.e. out-of-the-money. In that case, the EEX exchange adjusts the values of short option. 


\begin{tabular}{|c|c|c|c|}
\hline Contract & & \multicolumn{2}{|c|}{$\begin{array}{l}\text { C (CALL) O1BY (Phelix Base Year Option JAN13 } \\
\text { EUR } 61.00\end{array}$} \\
\hline Contract volume & & \multicolumn{2}{|c|}{365 days $\mathrm{x} 24$ hours $\mathrm{x} 1 \mathrm{MW}=8,760 \mathrm{MWh}$} \\
\hline Additional margin 1 & & \multicolumn{2}{|l|}{2.7} \\
\hline Position & & \multicolumn{2}{|l|}{$50 \mathrm{~L}$ or $50 \mathrm{~S}$} \\
\hline Daily settlement pri & tion & \multicolumn{2}{|l|}{0.802} \\
\hline Daily settlement pri & ectricity & \multicolumn{2}{|l|}{53.70} \\
\hline \multicolumn{4}{|c|}{ Premium margin } \\
\hline \multicolumn{2}{|c|}{ Long position } & \multicolumn{2}{|c|}{ Short position } \\
\hline $\begin{array}{l}\text { Premium margin } \\
=-50 \mathrm{x} 8,760 \mathrm{MWhx} 0 \\
=\mathrm{EUR}-351,276.00\end{array}$ & $\mathrm{R} / \mathrm{MWh}$ & \multicolumn{2}{|c|}{$\begin{array}{l}\text { Premium margin } \\
=50 \times 8,760 \mathrm{MWhx} 0.802 \mathrm{EUR} / \mathrm{MWh} \\
=\mathrm{EUR} 351,276.00 \text { (loss) }\end{array}$} \\
\hline \multicolumn{4}{|c|}{ Additional margin } \\
\hline \multicolumn{2}{|c|}{ Long position } & \multicolumn{2}{|c|}{ Short position } \\
\hline \multicolumn{4}{|c|}{ Future underlying asset } \\
\hline Projection & \multicolumn{2}{|c|}{ Daily settlement price } & Projection \\
\hline $51.00 \mathrm{EUR} / \mathrm{MW}$ & \multicolumn{2}{|c|}{53.70 EUR/MWh } & 56.40EUR/MWh \\
\hline \multicolumn{4}{|c|}{ Option } \\
\hline Projection & \multicolumn{2}{|c|}{ Daily settlement price } & Projection \\
\hline 0.670 & \multicolumn{2}{|c|}{0.802} & 1.489 \\
\hline $\begin{array}{l}\text { Worst case: Option } \\
\text { (for } 0.132 \text { ) }\end{array}$ & lls from 0.802 to 0.670 & \multicolumn{2}{|c|}{$\begin{array}{l}\text { Worst case: Option price rises from } 0.802 \text { to } 1.489 \\
\text { (for } 0.687 \text { ) }\end{array}$} \\
\hline $\begin{array}{l}\text { Additional margin } \\
=50 x 0.132 \mathrm{EUR} / \mathrm{MV} \\
=\mathrm{EUR} 57,816 \text { (loss) }\end{array}$ & 50MWh & \multicolumn{2}{|c|}{$\begin{array}{l}\text { Additional margin } \\
=50 \times 0.687 \mathrm{EUR} / \mathrm{MWhx} 8,760 \mathrm{MWh} \\
=\mathrm{EUR} 300,906(\mathrm{loss})\end{array}$} \\
\hline \multicolumn{4}{|c|}{ Total margin } \\
\hline \multicolumn{2}{|c|}{ Long position } & \multicolumn{2}{|c|}{ Short position } \\
\hline Premium margin & EUR - $351,276.00$ & Premium margin & EUR $351,276.00$ \\
\hline Additional margin & EUR 57,816.00 & Additional margin & EUR $300,906.00$ \\
\hline Margin loan & EUR -293,460.00 & $\begin{array}{l}\text { Total margin to be } \\
\text { furnished }\end{array}$ & EUR $652,182.00$ \\
\hline $\begin{array}{l}\text { The margin loan car } \\
\text { same margin class }\end{array}$ & off against margin for & $\begin{array}{l}\text { The seller has to dep } \\
\text { EUR } 652,182.00\end{array}$ & $r$ margin in the amount of \\
\hline
\end{tabular}

Table 3. An example of calculation of the premium and additional margin (EEX, 2016)

Since the option of the forward price of electric energy represents the subject of trade, it means that the option is added to the futures contract. The holder of the option and futures contract takes two assigned positions. The only difference is in obligations emerging from trading with options and futures contracts. The holder of the option and futures contract may compensate these margins summing them up mutually so as not to cover margins for each individual position. The margin emerged 
from the trading with option and margin emerged from trading with futures contract belong to the same margin class. The profit and loss emerged from the trading position per futures contract are calculated in the following manner:

Profit/loss $(E U R)=$ Position $x$ Contracted quantity $($ MWh $) \times$

(Designed forward price - Contracted forward price (EUR/MWh)

While the profit and loss emerged from the position of trading with option is calculated as:

Profit/loss $($ EUR $)=$ Position $x$ Contracted quantity $($ MWh $) \times$

Designed option price (EUR/MWh).

\begin{tabular}{|c|c|c|c|c|c|}
\hline \multicolumn{3}{|c|}{$\begin{array}{l}\text { Underlying asset of the margin class } \\
\text { (Phelix Base Year Future for year 2013) }\end{array}$} & \multicolumn{3}{|l|}{ F1BYJAN13 } \\
\hline \multicolumn{3}{|c|}{$\begin{array}{l}1^{\text {st }} \text { position } \\
\text { (Short Call Phelix Base Year Option for year 2013) }\end{array}$} & \multicolumn{3}{|c|}{ 50S CO1BY JAN13 €61.00 } \\
\hline \multicolumn{3}{|c|}{$\begin{array}{l}2^{\text {nd }} \text { position } \\
\text { (Long Phelix Base Year Option for year 2013) }\end{array}$} & \multicolumn{3}{|c|}{ 10L F1BY JAN13 $€ 53.70 /$ MWh } \\
\hline \multicolumn{3}{|c|}{ Contract volume (365 days x 24 hours x 1 MW) } & \multicolumn{3}{|l|}{ 8,760 MWh } \\
\hline \multicolumn{3}{|c|}{ Additional margin parameter } & \multicolumn{3}{|l|}{ 2.7 EUR/MWh } \\
\hline \multicolumn{3}{|c|}{ Daily settlement price of the underlying asset } & \multicolumn{3}{|l|}{53.70} \\
\hline \multicolumn{3}{|c|}{ Daily settlement of $1^{\text {st }}$ position } & \multicolumn{3}{|l|}{0.802} \\
\hline \multicolumn{3}{|c|}{ Daily settlement price of $2^{\text {nd }}$ position } & \multicolumn{3}{|l|}{53.70} \\
\hline \multirow{2}{*}{$\begin{array}{l}\text { Scanning } \\
\text { range }\end{array}$} & \multicolumn{2}{|c|}{ 50S CO1BY JAN13 €61.00 } & \multicolumn{2}{|c|}{ 10L F1BY JAN13 $€ 53.70 / \mathrm{MWh}$} & Portfolio \\
\hline & $\begin{array}{l}\text { Price in } \\
\text { EUR/MWh }\end{array}$ & $\begin{array}{l}\text { Amount for } \\
\text { closing }\end{array}$ & Change in $€$ & $\mathrm{P} \& \mathrm{~L}$ & $\begin{array}{l}\text { Loss when } \\
\text { closing }\end{array}$ \\
\hline $56.40 € / \mathrm{MWh}$ & 1.489 & 652,182 & 2.7 & $-236,520$ & 415,662 \\
\hline $53.70 € / \mathrm{MWh}$ & 0.802 & 351,276 & 0 & 0 & 351,276 \\
\hline $51.00 € / \mathrm{MWh}$ & 0.670 & 293,460 & -2.7 & 236,520 & 529,980 \\
\hline
\end{tabular}

Table 4. The overview of margin calculation of the same margin class (EEX, 2016)

Considering the example provided in Table 4 it is evident that the margin which is necessary to provide for options is EUR 652,182 and for futures contracts EUR 236,520 which would mean that the total requested margin is EUR 888,702. However, when the credit is transferred in between the margins which belong to the same margin class, it is obvious that the margin that covers the price increase risk is EUR 415,662 and it is less than the margin that covers the price reduction risk and amounts to EUR 529,980 which means that the total premium for contracts belonging to the same margin class is EUR 529,980.

In this case, also, the EEX exchange uses the Black 76 formula for the calculation of the option value taking into consideration the implied volatility which results from the current contracted option prices. Table 4 indicates an example of the calculation of margins which belong to the same margin class. 
Market liquidity, defined as a proportion of the total trading volume and energy consumption, called churn ratio, is highest in German Power Derivatives Market that significantly increased in the past, and it reached a level of 18. All other European power derivatives market areas have a churn rate of 5 , at a maximum. This parameter indicates how often a megawatt-hour of power is traded on the markets before it is actually physically delivered. The higher the churn rate, the higher the total trading volume and the liquidity of the market is.

Trade through SEEPEX is voluntary and no regulatory measures that would protect liquidity have been taken. In its first year of activity, 0.6 TWh has been traded on the SEEPEX Day-Ahead market. In May 2017, SEEPEX reached the highest traded volume, amounting to 107,222.7 MWh (SEEPEX, 2017a). Maximum traded volume per day was, also reached on 5th May 2017, when the traded volume was 8,270.6 MWh (SEEPEX, 2017b).

If we analyze liquidity of SEEPEX throughout three dimensions of liquidity of electricity market: volume, costs and time, we can easily conclude that it is not a liquid market. In terms of volume, the traded volume is small, market cannot absorb volume without having major impact on the price, the number of registered companies is also very small (by today there have been registered 14 companies, 2 are in the process of registration and 5 new participants are expected to be registered by the end of 2017, although, 6 other companies showed their interest in registering on SEEPEX during 2018) and there is almost no diversity between the parties present. In terms of cost, there is high price volatility, in its first year of activity, the average monthly reference price was between EUR 25.01 and EUR 82.88 (EPEX, 2017), trading costs were significant. Regarding the time, we should take the number of transactions into consideration, which show how quickly transaction can be made at any time and percentage of days transactions were handled on. It is noticeable that during weekends just a few companies participated, which reflected on traded volume. Price and quantity depended on the season and situation throughout the region. Prices follow the tariff and consumption trends in Europe, mostly on HUPX, which is not the case with Serbia. The national market is insufficient to achieve liquidity.

Measures that could impact positively on increasing market liquidity are:

1. Increasing the number of participants and business energy users on organized market,

2. Market coupling initiatives,

3. Investments in interconnection capacities,

4. Harmonization of market rules relating to network access, balancing and incentives for new network investments,

5. Removal of regulated end-user prices,

6. Improving transparency.

This example demonstrates the multi-dimensionality of the process of calculating the value of options using recognized scientific methods in this field. Recognizing the essence of these processes is the quality that extends the scopes of scientific truth.

\section{CONCLUSIONS}

The process of globalization on the world markets for electric energy systems primarily involves restructuring and liberalization of the electricity and energy markets. Serbia is included in that process through changes which occur in the electrical industry and energy sector in the region and the European Union (Jeremić, 2006). As a part of these changes, the Serbian exchange of electric energy SEEPEX 
in partially ownership of EPEX, which has the leading role in joining markets of electric energy in Europe, was put in operation in the early 2016. It is a spot market with numerous obstacles in the path of its development, taking into consideration the specific and complex features of the electric energy market. This market is very risky, with high volatility and numerous risks due to which the participants may suffer losses. Therefore, on the developed markets and in the sphere of electric energy trading the development of derivatives which, like in other financial and goods exchanges, have the function of risk management, takes place. This paper deals with the use of one type of derivatives, the option on electric energy. This role is possible to be explained only by the example of the most developed markets, such as EEX, Leipzig since this market is liquid and all types of derivatives are used there. Experience of developed power exchanges should be used in the process of developing the SEEPEX. We have explained one segment of the liquid market that could be used as a future model of development, as a model of good practice.

Analyzing the results, using one type of derivatives (options on electric energy) must be understood as an analysis of a part belonging to the system where all types of derivatives are present. It is dangerous to draw conclusions about the whole, by observing the part. Awareness of the essence that influence a part is useful. The results provided in this work have this purpose, especially since the applied method of part (the option-risk) is verified on the market where all derivatives are used.

Future prices are directly linked with the movement of spot prices so while using the instruments such as futures, forwards and options the starting point is the spot market. The prediction done in a quality manner related to future price movements based on the current prices and all risk factors which exist with these trading objects are the basis for successful trading. Although the model for creating prices may be sophisticated, if the curve of the future price movement is not adequate, error in price creation will outweigh all benefits which a sophisticated model may offer. With options for the hedging of future open positions and evaluation of premiums to options, the most frequently used models in practice are the Black-Scholes and Black 76 models, which are therefore the subject of this research.

The use of all types of derivatives in trading with electric energy is necessary for the purpose of protection from risk and optimization of exposure. So the knowledge on the use of derivatives on the electric energy markets is indispensable for the participants in less-developed markets as well. Hedging of the market risk is a way to reduce and eliminate the risk of price change, although it is necessary to be aware of numerous limitations which reduce the usage value of existing models which are applied in practice for the purposes of reducing the risk during the trading with options.

\section{REFERENCES}

Black, F. (1976). The Pricing of Commodity Contracts. Journal of Financial Economics, 3(1-2), 167-179. DOI: 10.1016/0304-405X(76)90024-6.

Black, F., \& Scholes, M. (1973). The Pricing of Options and Corporate Liabilities. Journal of Political Economy, 81(3), 637-654.

Blanco, C., Choi, S., \& Soronow, D. (2001). Energy Price Processes Used for Derivatives Pricing \& Risk Management. Retrieved August 6, 2017, from http://web2.uwindsor.ca/courses/business/assaf/a_brownian.pdf.

Davis, M. (2001). Mathematics of Financial Markets. Retrieved August 6, 2017, from http://wwwf.imperial. ac.uk/ mdavis/docs/math2001.pdf.

Edwards, D. (2010). Energy Trading and Investing. New York: McGraw Hill. 
EEX. (2017a). At the Heart of Energy and Commodity Trading: Markets and Products 2017. Retrieved August 01, 2017, from https://www.eex.com/blob/63998/e18188dc9db9943679977aa4a78d943e/neu-e-eex-broschuere2017-web-data.pdf.

EEX. (2016). Trading Power Options at European Energy Exchange. Retrieved August 01, 2017, from https://www. eex.com/blob/9168/f4acb98587096346ecabc6af86bbc8fd/trading-power-options-at-eex-data.pdf.

EEX. (2017b). Power Derivatives Market. Retrived July 31, 2017,from https://www.eex.com/en/products/power/ power-derivatives-market.

EEX. (2017c). Settlement Pricing Procedure. Retrieved August 05, 2017, from https://www.eex.com/blob/61950/ 901173f518c73dbe63d31b146fcf6e50/settlement-pricing-procedure-data.pdf.

EMS. (2016). SEEPEX uspešno pokrenuo srpsko Dan-unapred tržište. Retrieved August 01 from http://www.ems. rs/news_more.php?id=260. In Serbian.

EPEX. (2017). SEEPEX Power Market Forms Bridge between Regions. Retrieved August 012017 from https:// www.epexspot.com/en/.

Eurexchange. (2017). Glossary. Retrieved August 15, 2017, from http://www.eurexchange.com/exchange-en/ education/glossary.

Eydeland, A., \& Wolyniec, K. (2003). Energy and power risk management: New developments in modeling, pricing, and hedging. Hoboken, NJ: Wiley.

Fritz, A. (2012). European electricity and Interrelated Futures Market: A cointegrated Vector Autoregressive Analisis. Retrieved August 6, 2017, from http://www.ewl.wiwi.uni-due.de/fileadmin/fileupload/BWL-ENERGIE/ Arbeitspapiere/RePEc/pdf/wp1205_EuropeanElectricityAndInterrelatedFuturesMarketsACointegratedVectorAutoregressiveAnalysis.pdf.

Hull, J. (2005). Options, Futures and Other Derivates. Upper Saddle River, NJ: Prentice Hall.

Jeremić, Z. (2006). Energetski sektor: šansa za razvoj finansijskog tržišta u Srbiji. Ekonomski anali, No. 51, 61-71. In Serbian.

Jeremić, Z. (2012). Finansijska tržišta i finansijski posrednici. Beograd: Univerzitet Singidunum. In Serbian.

Madlener, R., \& Kaufmann, M. (2002). Power exchange spot market trading in Europe: theoretical considerations and empirical evidence. Retrieved May 6, 2017, from http://www.oscogen.ethz.ch/reports/oscogen_dp5_010702.pdf.

Mishra, B., \& Debasish, S.S. (2007). Financial Derivatives. New Delhi: Excel Books.

Orsag, S. (2006). Izvedenice. Zagreb: Hufa.

Pavlatka, P. (2010). Option Derivatives in Electricity Hedging. Acta Polytechnica, 50(4), 65-69.

Pilipovic, D. (2007). Energy Risk: Valuing and Modeling Energy Derivatives. New York: McGrow-Hill Professional.

Salvatore, D. (1994). Ekonomija za menadžere u svjetskoj privredi. Zagreb: Mate. In Croatian.

SEEPEX. (2017b). 05.05.2017. - SEEPEX ostvario najveću dnevnu količinu trgovine. Retrived August 10, 2017, from http://seepex-spot.rs/sr/novosti/05-05-2017-SEEPEX-ostvario-najvecu-dnevnu-kolicinu-trgovine. In Serbian.

SEEPEX. (2017a). 107.222,7 MWh - Novi mesečni rekord! Retrieved August 10, 2017, from http://seepex-spot. rs/sr/novosti/u-maju-novi-mesecni-rekord-trgovine. In Serbian.

Tešnjak, S., Banovec, E., \& Kuzle, I. (2009). Tržište električne energije. Zagreb: Graphis. In Croatian. 


\section{OPCIJE NA ELEKTRIČNU ENERGIJU RADI SMANJENJA RIZIKA NA PRIMERU EEX (EUROPEAN ENERGY EXCHANGE)}

\section{Rezime:}

Deregulacija i liberalizacija tržišta električne energije dovele su do visoke volatilnosti na berzama električne energije, što zahteva upotrebu derivata na energetskim tržištima radi efikasnijeg upravljanja rizikom kojem su izloženi učesnici na tržištu. Opcije su jedan od derivata koji se primenjuju na likvidnim tržištima, pa je stoga u tekstu obrađen primer sa najrazvijenije energetske berze EEX (European Energy Exchange) sa ciljem da se primenom verifikovanih naučnih metoda proveri praksa funkcionisanja likvidnog energetskog tržišta primenom opcija radi smanjenja rizika. Kod opcija je za hedžovanje budućih otvorenih pozicija i evaluaciju premija na opcije u praksi najkorišćeniji modeli Black-Schols model i Black 76, koji su stoga i obrađeni u tekstu. U Srbiji je počela sa radom berza električne energije SEEPEX (South East European Exchange). Njen razvoj vodiće preko integracije sa regionalnim tržištima u pravcu integrisanja ukupnog tržišta električne energije u Evropi. Taj put biće dug, ali, već sada, on zahteva i poznavanje tržišnih instrumenata koji se koriste u trgovanju i upravljanju rizikom na berzama električne energije. Prikazani rezultati se odnose na suštinsku spoznaju dinamičnih varijabli koje opcije unose na tržište energenata radi smanjenja rizika.

\section{Ključne reči:}

berza električne energije, derivati, opcije. 